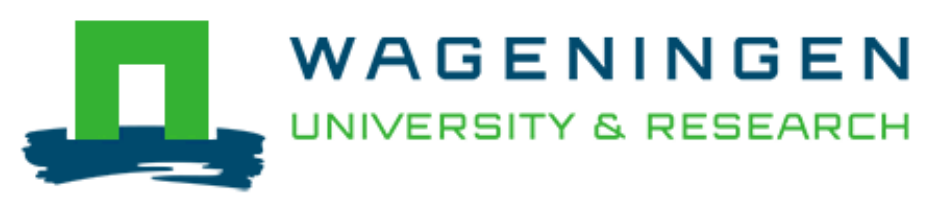

\title{
Belonging to and in the Shale Gas Fields. A Case-Study of the \\ Noordoostpolder, the Netherlands
}

\author{
Köhne, M., \& Rasch, E. D.
}

This is a "Post-Print" accepted manuscript, which has been published in "Sociologia Ruralis"

This version is distributed under a non-commercial no derivatives Creative Commons (c) (1) (9) (CC-BY-NC-ND) user license, which permits use, distribution, and reproduction in any medium, provided the original work is properly cited and not used for commercial purposes. Further, the restriction applies that if you remix, transform, or build upon the material, you may not distribute the modified material.

Please cite this publication as follows:

Köhne, M., \& Rasch, E. D. (2018). Belonging to and in the Shale Gas Fields. A CaseStudy of the Noordoostpolder, the Netherlands. Sociologia Ruralis, 58(3), 604-624. DOI: $10.1111 /$ soru. 12184

You can download the published version at:

https://doi.org/10.1111/soru.12184 


\title{
Belonging to and in the shale gas fields.
}

\section{A case study of the Noordoostpolder, the Netherlands}

\begin{abstract}
This article analyses how belonging becomes articulated in relation to large-scale extractive projects. It does so through an ethnographic analysis of the construction of belonging expressed in languages of valuation (the meanings that people give to natural resources discursively and in practice) in the Noordoostpolder, the Netherlands. Belonging is understood to encompass 'feeling at home in a place' and the political processes through which belonging becomes a discursive resource (the politics of belonging). We conclude that the ways people position themselves toward shale gas extraction are both rooted in how they give meaning to and interact with their environment and embedded in local history and ideas of political agency and voice. Only those elements of belonging that are considered objective or useful as policy solution are used as a discursive resource in mobilisation against shale gas. The article is based on 2,5 years of ethnographic fieldwork.
\end{abstract}

\section{Introduction}

In this article we analyse how belonging becomes articulated in relation to large-scale extractive projects. Extractive landscapes are inhabited by economic, historical and ideological values that are constructed through peoples' engagement with the environment. Extractive projects therefore tend to have considerable impacts on the ways in which people experience placebelongingness. This is especially true for shale gas developments, as the way of extracting it from shale rock layers, hydraulic fracturing, has far-reaching impacts on the lived environment in terms of drinking water, traffic noise, landscape pollution and health. Shale gas developments therefore often encounter major resistance from communities nearby (proposed) extraction 
locations (Rasch \& Köhne 2016, Hudgins \& Poole 2014, Perry 2011, De Rijke 2013). Place, land and landscape constitute particularly important aspects of belonging in such social mobilisations because of the foreseen impact of hydraulic fracturing on the lived environment, amongst others (Willow et al., 2014). Which aspects of belonging become articulated in relation to shale gas developments, and how, is far from unambiguous. In the Dutch Noordoostpolder, the case study central to this article, only those elements of belonging that could be expressed in facts and numbers or translated to concrete policy solutions, such as those related to monetary values and renewable energy goals, became explicitly articulated in anti-shale gas mobilisations.

The central aim of this article is to analyse how belonging becomes articulated in relation to shale gas developments. We do this at three levels. First, we examine which elements of belonging are articulated in relation to shale gas and hydraulic fracturing and how these elements are constructed in time and space. Second, we go into the ways in which these elements of belonging relate to and shape the process of taking position towards shale gas developments. Third, we analyse why some aspects of belonging are used in anti-shale gas mobilisations, while others are not. We are, thus, less concerned with the process of social mobilisation itself but rather focus on unpacking how belonging relates to this process. Belonging, then, is briefly understood as to encompass a personal feeling of being 'at home' on the one hand and to constitute a discursive resource used to justify forms of in- and exclusion on the other (Yuval Davis 2006). Inspired by the work of Martinez-Alier (e.g. 2009) we analyse different facets of belonging as reflected in and constructed through different languages of valuation. Languages of valuation grasp the voicing of different meanings of natural resources discursively and in practice. 
By unpacking these layers of belonging and how they are articulated, we demonstrate how the ways people articulate belonging in relation to shale gas developments is rooted in localised meanings and values of natural resources. In doing so, we add to two important bodies of (fracking) literature. First, we contribute to the important work that has already been done on the belonging-resistance nexus and which shows how place-belongingness, land and landscape shape resistance against shale gas extraction (Willow et al., 2014) and how hydraulic fracturing might produce experiences of losing control over the environment (Hudgins 2013). In this article we take this a step further by explicitly analysing why specific elements of belonging are translated into arguments used to claim rights in the politics of belonging. Second, our focus on how people who live on or near proposed extraction sites articulate specific elements of belonging in relation to shale gas developments adds to the literature on fracking in communication studies. This literature analyses framing strategies in media and policy documents demonstrating how different actors discursively influence environmental policies and how frames (and meanings) are mobilised to do so (e.g. Bomberg 2015, Cotton et al., 2014; Metze 2014). ${ }^{1}$

Our argument consists of three interrelated claims that emerge from our findings. First, the elements of belonging people articulate in relation to shale gas developments are related to the meaning they give to the place and landscape they live in. These meanings are reflected in different languages of valuation and shape the processes of determining what they think of shale gas. As such, secondly, all languages of valuation related to shale gas developments contain an element of voice and political agency. However, not all languages of valuation become discursively used in the course of social mobilisation. The aspects of belonging that do become 
explicitly part of resistance against shale gas developments - and this is the third claim - are those that are considered the most 'factual' and 'objective' or suitable as policy solution.

Theoretical framework: belonging and the valuation of natural resources Belonging is generally conceptualised along a public-private continuum (Lähdesmäki et al., 2016) and encompasses a personal, intimate, feeling of being 'at home' on the one hand and a discursive resource that negotiates forms of socio-spatial in/exclusion on the other (Yuval Davis 2006). As a concept, belonging is closely related to, and often conflated with, identity (Antonsich 2010). However, belonging more explicitly analyses the relation between human experience and the material world and emphasises physical proximity over common identity (Probyn 1996, Lähdesmäki et al., 2016).

The personal dimension of belonging, 'place-belongingness', focuses on the personal meanings people give to the place they live in. 'Home' here stands for a symbolic space of familiarity, comfort, security, and emotional attachment (hooks, 2009; Duyvendak, 2011). Authors have made different categorisations of factors that may contribute to place-belongingness. Antonsich (2010) distinguishes the following: auto-biographical (place-based experiences and memories), relational (personal and social ties), cultural (such as language, but also shared rituals, ceremonies and popular culture), economic (safe and stable material conditions), and legal (formal citizenship and resident permits). Other authors also mention safety (being or not being exposed to crime and violence) and politics (as a way of channelling voices and sharing values, feeling represented) as important facets in which a feeling 'at home' is constructed (Mulgan, 2016; Buonfino \& Thomson, 2007). In natural resource conflicts political, economic and autobiographical dimensions of belonging appear to be important. 
Another important element in the construction of personal belonging in relation to natural resource extraction is that of physical space, landscape and environment. The physical character of places affects how people develop a sense of belonging (Buonfino \& Thomson, 2007; Mulgan, 2016). However, belonging is not just shaped by the environment itself; belonging is also constituted in people's everyday life interactions with land and nature through livelihoodrelated or other everyday practices that produce emotional attachments (Poe et al., 2014). Belonging through relations with the lived environment is often articulated in relation to shale gas projects and other extractive projects such as open pit mining, because of the far-reaching consequences for that lived environment (Poole \& Hudgins, 2014; Willow et al., 2014).

The 'politics of belonging' refers to the processes through which aspects of personal belonging as described above become political. This can happen in two ways: one, politics of belonging are used to in/exclude people from social groups on the basis of personal elements of belonging and two, in the politics of belonging the intimacy of belonging becomes a political tool itself and elements of belonging are mobilised to claim rights and inclusion. Belonging is, thus, not an isolated and individual affair (Probyn, 1996: 13). Antonsich (2010: 12) describes the link between the two domains as follows: 'One's personal, intimate feeling of belonging to a place should always come to terms with discourses and practices of socio-spatial inclusion/exclusion'. This is different from identity politics as it includes more affective dimensions in the experiences and practices of belonging, than the emancipatory focus that is often part of theorisations of identity politics (Lähdesmäki et al., 2016; Gerhartz, 2014). In studies about politics of belonging the link with emotive attachments remains under- theorised (Antonsich, 2010). This resonates with our observation that notwithstanding the importance of affective elements of place-belongingness, 'emotive' reasons are not brought forward in the debate on hydraulic fracturing, reflecting the 
marginalisation of such arguments in debates where 'scientific' and economic arguments hold more power (Chilvers \& Kearnes, 2015).

In the politics of belonging in conflicts over extractive projects place-belongingness plays an important role as a discursive tool to negotiate rights, as extractive projects tend to have large impacts on the lived environment. Conflicts are mainly negotiations about who gets to decide on natural resource use. People often feel excluded from the political community in terms of decision-making processes, and uninvited energy plans are often seen as an infringement of political rights. In conflicts over shale gas developments people's feelings of political exclusion are prevalent (Hudgins, 2013; Willow et al., 2014).What people 'long for' (Probyn 1996) is to belong to the political community that makes decisions about the use of natural resources.

Resource conflicts are thus often rooted in different ideas about the meanings of a resource and not 'just' struggles over scarcity. Different meanings of natural resources may be voiced in different, potentially clashing, languages of valuation, such as environmental justice, indigenous territorial rights, environmental security or monetary valuation (Martinez-Alier, 2001). These languages of valuation ascribe sociocultural, historical, and/or physical characteristics to resources that support the argument of the projected narrative with the intention of gaining 'control' (Vandergeest \& Peluso, 1995). The ways environmental conflicts are framed, that is, the way people discursively evaluate what the conflict is about and how it should be solved (Lewicki \& Gray, 2003), may be rooted in these languages of valuation that describe the meanings given to the lived environment. Languages of valuation thus grasp the ways different groups attach varying meanings to natural resources, and how these meanings can clash and produce conflicts over resource use. 
To sum up, we approach the politics of belonging as a process through which inclusion in decision-making processes about natural resource use is claimed. In such processes different facets of place-belongingness are mobilised through languages of valuation. These contain autobiographical, relational, cultural, economic and legal ties, as well as ideas about voice and political agency.

\section{Context: Fracking rural places in times of energy transition}

While hydraulic fracturing as an extraction technique has been used for decades to extract oil and gas, it was only in the late 1990s that it was combined with horizontal drilling, opening up the exploitation of deep shale rock layers. In 2004 shale gas was first extracted in Pennsylvania. The area soon became an epicentre of the Marcellus shale boom (Willow 2016). ${ }^{2}$ In Europe, exploration licenses have been granted in several countries (France, the United Kingdom, Poland, Romania and The Netherlands, among others) from 2010 onwards, but following environmental protests most governments have recently put a moratorium on hydraulic fracturing (e.g. Vesalon \& Creţan, 2015) in contrast to the United States and Canada, where shale oil and gas development has proceeded relatively unchallenged, despite ongoing protests (Eaton \& Kinchy, 2016; Simonelli, 2014).

The shale gas industry and its supporters draw primarily on a neoliberal framework to justify shale gas extraction. They argue that it brings direct and indirect economic benefits, such as the construction of superior roads, employment, increased tax revenues and improved education (Willow, 2016). A second argument is that the development of domestic shale resources is essential for energy independence of Europe as well as the United States (Perry 2012; Bomberg, 2015). In addition, natural gas is presented as a cleaner alternative to coal (Mercer et al., 2014; 
Finewood \& Stroup, 2012). Finally, it is argued that shale gas extraction will be safe in Europe as it would be based on caution, sound science and robust regulation (Metze 2014). However, studies show that economic benefits associated with fracking are often overstated and temporary (Barth, 2013), that greenhouse gas emissions are higher than originally presumed (Howarth et al., 2010) and that fracking seriously compromises the quality and availability of water (Entrekin et al., 2011) and releases toxic substances harmful to public health (Colborn, 2011).

Peoples' perceptions towards shale gas have mainly been studied in the United States by the use of surveys (Willow, 2016), showing how perceptions are shaped by demographic factors (e.g. Brasier et al., 2011; Jacquet, 2012) environmental attitudes (e.g. Davis \& Fisk, 2014) and media effects (e.g. Boudet et al., 2013). Qualitative research addressing how fracking impacts people's lives and how they perceive fracking shows how citizens are often guided by a more holistic, i.e. not just economic, perspective when they evaluate hydraulic fracturing in their near surroundings. They bring forward arguments against fracking that relate to public health, community continuity, political empowerment, and environmental sustainability (Willow, 2016). Recent studies in Europe show that citizens do not only experience threats to the environment and their community, but also to democracy in general. Opposition is thus not only directed at fracking itself (substantial values), but also at the process surrounding its regulation and development (procedural values) (Correljé et al., 2016; Bomberg, 2015; Vesalon \& Creţan, 2015).

The Netherlands' consumption of energy is one of the most fossil oriented in Europe, $94 \%$ in $2014^{3}$, of which $40 \%$ is coming from natural gas ${ }^{4}$; most of it being extracted from the Groningen gas fields in the north of Holland. All such subsoil resources are state property, which means 
that landowners have no rights to benefits from these resources apart from compensation for use of their property or for drilling related damages. Conflicting interests within communities are therefore far less than in, for example, the United States. Here, landowners who manage to strike a good deal with drilling companies can become rich (Brasier et al., 2011). In the Netherlands, conflicts are rather between the governments and local communities that bear the consequences of (gas) extraction. This is also the case in the depleting gas fields in Groningen where regular 'gasquakes' result in a growing resistance towards further extraction (Metze 2014).

In this light the Dutch government argued that shale gas extraction would be cleaner than coal and as such could be considered a transition fuel towards renewable energy. Without public consultation, permits for exploratory drilling in The Noordoostpolder and Boxtel were granted by the national government to the United Kingdom based company Cuadrilla. Test drilling was supposed to start in 2013 in Boxtel, and in 2014 in the Noordoostpolder. ${ }^{5}$ However, due to strong resistance (see BLINDED for REVIEW, Metze 2014), shale gas framing by the Dutch government transformed from 'green' and 'business as usual' towards 'uncertain' and 'environmentally risky' (Metze 2014), resulting in a moratorium until 2023.

\section{Methodology}

Doing research about the social dynamics of extractive projects often means becoming part of the social change that the involved communities aspire. This is because natural resource conflicts in the domain of large-scale extraction always imply structural differences in power between companies and the involved communities. Inspired by the call for a more engaged anthropology in the domain of extraction research (Kirsch, 2002), our research is designed as an 
engaged ethnographic case study, which 'entails a commitment to generating the kinds of knowledge they [involved organised groups or communities] ask and need us to produce' (Hale, 2006: 113). This means that we engaged with the main partnership against shale gas 'Tegengas' and involved our research participants in the course of the research. This obviously shaped our research findings, and may have limited our access to proponents of shale gas developments. It did, however, provide us with access to research data that we would not have had access to without our explicit engagement with Tegengas: access to meetings, meeting minutes and being on the first row of all their activities (see also BLINDED FOR REVIEW) Also, our research in the Noordoostpolder has not been limited to following Tegengas, but included a much wider network of research participants.

The case study that we present in this article is based on fieldwork in the Noordoostpolder between April 2014 and July 2016. This timeframe can be divided into three intensive interview rounds that took place in April-June 2014, October-November 2014 and May-June 2016. In between we regularly travelled to the Noordoostpolder to conduct participant observation during specific activities related to shale gas and renewable energy. As the three most important chunks of fieldwork had their own logic, and focused on differing topics and as such involved varying research participants, we briefly discuss these intensive periods separately below.

When we started in April 2014 with interviews and participant observation in several activities related to shale gas, our first contact in the field directly led us to the main activist and via snowball sampling we got in touch with other residents involved in resistance, but also with politicians and proponents of shale gas and/or sceptical of the resistance organised. During this phase we focused on mapping and exploring how people experienced the proposed plans for hydraulic fracturing and the initiatives that had been developed against shale gas. Because of 
the exploratory character of this fieldwork we did unstructured and semi-structured interviews with a wide range of people: activists (local and national level), local politicians, people that engage in only some acts of resistance, residents living near to the proposed drilling sites, and proponents of shale gas. We conducted participant observation during an information meeting organised by the municipal council about shale gas.

In October 2014 we started a second round of interviewing, now focusing more directly on two themes that came to the fore through an inductive process of thematic coding (Ryan and Russel, 2003): social mobilisation as a form of citizenship and belonging, decision making and the different meanings and valuations of the Noordoostpolder. We interviewed people who were directly involved in social mobilisation against shale gas as to get grip on how political mobilisation would relate to more intimate feelings of belonging. In this period we also became involved in the Tegengas partnership that was organised to resist shale gas and represents different sectors of the municipality. By way of participant observation we started to join their meetings and the activities they organised, from going to a manifestation to support the activists from Groningen, to participating at their informal gatherings and joining information evenings they organised.

The moratorium of shale gas (2016) did not stop Tegengas from organising; the partnership still meets every month, closely following Dutch energy policy making and seeking media attention whenever this seems helpful for their case. Following up on the strong link we found between opposition to shale gas and support for renewable energy, we organised a third round of interviews in May-June 2016, in which we focused on renewable energy practices. During this round of interviews we interviewed people who engage in a wide range of 'renewable energy practices': individuals who want to live 'off the grid', farmers that invest in wind parks and solar 
panels by of diversifying their farming activities and municipal employees and policy makers that work on sustainability issues.

In total we interviewed 52 people who relate in different ways to the shale gas issue. The data that we collected through interviews were validated through participant observation, news analysis, textual and semi-textual document analysis and by discussions among researchers and with research participants. During the whole fieldwork period we conducted participant observation in Tegengas meetings, at peoples' homes, during manifestations against shale gas, at press conferences, preparatory meetings of Tegengas activities, in the visitors centre of the new wind park, at local museums. We also performed news analysis of the local newspapers, textual and semi-textual artefact analysis of (semi) textual artefacts produced by Shale Gas Free Noordoostpolder, Friends of the Earth and the municipal council: the websites they produce, the minutes of the Tegengas meetings, the posters, press communications, communications with politicians.

The names of the people who we have interviewed have been changed to protect their identities. Research participants, however, who participate in the public debate and have been interviewed by national newspapers and television, have maintained their own names. We have always presented ourselves at researchers when introduced to new people and research participants have agreed orally to participate in the research. Interviews and conversations, as well as observations have been recorded in a fieldlog and fieldnotes. The data were analysed through a process of thematic analysis. This means that all data were reviewed, coded thematically and reviewed again. As such, there has been an on-going analysis to refine the themes and the story the analysis tells (Braun \& Clarke, 2006). The themes that emerged from this analysis were grouped according to different elements of belonging that emerge from 
literature; autobiographical, economic, physical and ideological elements emerged as important elements to construct a feeling of 'being at home in a place'. These elements of belonging to the Noordoostpolder in relation to shale gas developments and are represented in different languages of valuation and structure the Findings section: the history of the polder (autobiographical facets); the productivity of the polder land (economic facets), the economic development of the municipality (economic facets), the Noordoostpolder landscape of regularity and tranquillity (physical facets); and the image of the Noordoostpolder as a producer of renewable energy (ideological facets). These languages of valuation do not necessarily represent different groups within the Noordoostpolder, but rather different ways of relating to this place. Some of them are also used politically in mobilisations against shale gas. In what follows we unpack these languages of valuation. In doing so, we show how place-belongingness is constructed from below and how belonging becomes political through these languages of valuation.

Findings: Belonging and languages of valuation in the Noordoostpolder

In this section we unpack belonging in relation to extractive industries through an ethnographic analysis of how Noordoostpolder inhabitants' articulations of belonging are reflected in different 'languages of valuation'. From our fieldwork several facets of belonging emerged that coincide with the literature (e.g. Antonsich 2010, Lähdesmäki et al., 2016) in five different languages of valuation ascribing different meanings and values to the land. Although they are sometimes closely related we will discuss each of these languages of valuation separately, discussing, first, how in these languages of valuation elements of belonging relate to and shape the process of taking position towards shale gas developments, and, second, why some aspects 
of belonging are used in anti-shale gas mobilisations, while others are not. But first we provide some background on the Noordoostpolder.

\section{Background on the Noordoostpolder}

The Noordoostpolder is a municipality in the north of The Netherlands with 46.603 inhabitants (CBS 2016). The $460 \mathrm{~km}^{2}$ is divided in Emmeloord, the main town of the municipality, and ten surrounding villages, planned to be on biking distance from each other. The municipality was reclaimed from the sea in the 1930 s and 1940 s as part of the Zuiderzee works, which entailed draining parts of the Zuiderzee and transforming them into polders, making them usable for agriculture (Groenman et al., 1952). The Noordoostpolder became inhabited in 1942 by the first pioneers. When Noordoostpolder residents learned about the plans for shale gas development, they started to organise against it. Central elements in the protests were not only the environmental and health risks, but also the right to be informed and to be part of the decisionmaking process. 'Noordoostpolder Shale Gas Free' organised in 2013 to mobilise residents and local politicians. A year later, the municipal council took position against shale gas and a new citizens committee was formed: 'Shale Gas No Noordoostpolder'. In November 2014 different initiatives came together in the partnership 'Tegengas'. ${ }^{6}$ Tegengas reflects different groups in the Noordoostpolder and consists of representatives of village councils, Shale gas Free and Shale gas No, the public health sector, the corporate sector and the municipality. They disseminate knowledge and information about shale gas and lobby politicians at the national level. The arguments that they bring to the fore against shale gas focus on the economic damage that shale gas extraction could cause, its incompatibility with the transition towards renewable energy and the specific risks it poses for the environment and public health. ${ }^{7}$ 
The Noordoostpolder as 'land of the pioneers'

The 'Pioneer Museum' is not difficult to find and is housed in one of those typical barns that characterise the Noordoostpolder. As we enter, Albert, the founder, approaches us. He immediately starts to show us around. As he guides us from maps of different proposals for reclaiming the land from the sea, to pictures of workforces of young men, working the mud while living in barracks hoping for a farm, to portraits of families that started to live in the polder in the 1940s, he talks us through his personal history. When his father, a polder pioneer, died, he had found boxes full of old pictures. Going through the pictures, he had felt the urgency to share the history of the Noordoostpolder with the rest of the world. So he opened the pioneer museum and started giving lectures in the whole country. It is impressive. Not only the enormous amount of pictures, information and history that is present here, but also Albert's passion to share the unique history of the polder. ${ }^{8}$

'Pioneers' refers to the people who worked in the polder to reclaim the land from the sea and subsequently were selected to be the first settlers on this new land (van der Meer 2014). Many inhabitants view the Noordoostpolder as the 'land of the pioneers', an autobiographical factor of place-belongingness that shapes the way people think about shale gas extraction (Antonsich 2010).

Our impromptu museum tour illustrates how Noordoostpolder inhabitants value their memories of pioneering. These are memories of hardship and pride, about dealing with endless slabs of mud without any protection against the weather while working to build a community from scratch. Farmers were selected on strict criteria: they should be excellent farmers, stand out in social qualities and be married to good housewives. To ensure a stable food production and a socially stable community, the Directie, the government agency responsible for the 
settlement procedures in the polder, put a lot of effort into organising community life through social evenings with cabaret and lectures from 1942 onwards (Flokstra 2000). However, in 1944 villagers took things in their own hands, organising associations for sports, theatre, music and village festivals and establishing village associations to act as intermediary between themselves and the Directie (Flokstra 2000). This role of pioneers and their descendants in the social organisation of the polder is still acknowledged. 'Local leadership always emanates from the rural roads' Annette concludes when we discuss the topic with her. In interviews, many descendants from pioneers still refer to their ample membership of sports clubs boards, village association boards and other volunteer functions in the villages. Marcel, who moved to the polder from Amsterdam, acknowledges this: 'these historical farmers are the village, they are the decision-makers around here ... they are the silent force behind what has been achieved in this area'.

The role of the pioneers is important in creating a memory of a shared past and as such an important element of people's familiarity and emotional attachment to the Noordoostpolder. This past is heralded during anniversaries of the polder and through exhibitions and a canon that narrate its history. ${ }^{9}$ Contemporary social organisations refer to this shared memory through their names, such as the 'Pioneers of the Future', which develops several sustainability initiatives mainly around food and energy for the Noordoostpolder. ${ }^{10}$ In these representations the pioneer' comes forward as a powerful figure that is associated with entrepreneurship, heroism, rationality and a strong voice. This image is in strong contrast with the way it was decided to give out concessions for shale gas exploration: without participation of the population. The shale gas related risk of pollution and experiences of political exclusion are considered as incompatible with the pioneer past. As John, a pioneer-son, explained to us, while looking out over the polder: 
'our parents have reclaimed this land from the sea with their bare hands, so how can you even think of placing a drilling rig here?'

The polder as 'land of the pioneers' is an autobiographical factor of place-belongingness that shapes the way people think about shale gas developments and the voice they should have in deciding upon it; arguments against shale gas extraction are related directly to this past. However, as an 'emotive' and 'affective' character, it is not brought forward in political negotiations about shale gas. The pioneer past does not appear on fact sheets or in visualisations on posters, is not discussed in meetings, nor is it made explicit in presentations to the outer world. This language of valuation thus plays an important role in peoples' political positioning towards shale gas, but does not develop into a politics of belonging, as it is not used as discursive tool in overt resistance against it.

Making a living: The Noordoostpolder as productive land At the information meeting at $L T O,{ }^{11}$ initiated by Cuadrilla, it is time for questions. Farmers want to know what is in it for them if shale gas extraction comes to the Noordoostpolder. The discussion peaks when Cuadrilla claims that they will indeed compensate for damages directly caused by the extraction process. While some farmers murmur approvingly, others gesture their disbelief. Then Rick takes the microphone: 'the problem with shale gas in the Noordoostpolder is that even if everything goes well, it can go terribly wrong ... if consumers of potatoes or companies that we sell potato seedlings to, get worried about shale gas, even when there is absolutely zero residue of chemicals on our potatoes, they will not buy from us anymore [...] our image will be damaged and that will affect our income.' And although the Cuadrilla representatives had promised that all damages would be compensated, they could not come up with a satisfactory answer to this remark. ${ }^{12}$ 
Rick is one of the farmers who resist future fracking in the Noordoostpolder. His point of view is widely supported by farmers and entrepreneurs of the Noordoostpolder, emphasising the Noordoostpolder as productive land in which the export of potato seedlings plays an important role. This local, historical meaning of productivity is considered incompatible with shale gas extraction. As an economic facet of place-belongingness (Antonsich 2010) it has turned into a powerful language of valuation in the course of social mobilisation against shale gas.

The Noordoostpolder as productive land is rooted in the creation of the polder, which was driven by the need for new productive farmland to deal with food shortages (van Hulten, 1968). That is why being a good farmer with knowledge of modern farming techniques and financial solvability were important criteria for being selected (Constandse, 1958). Agrarian productivity as a criterion for inclusion has become internalised by today's Noordoostpolder inhabitants. This aspect of belonging is for example expressed by Noordoostpolder farmers whoconsider their farm 'as a way of putting yourself in society'. This corresponds with more general findings in the literature on farmers' identity, which shows that autonomy and independence are, or at least were, core values of a farmers' identity (Van der Ploeg, 2012). In the Noordoostpolder, the autonomy of the farmer is perceived to be limited by the possibility of damaging production on neighbouring land as well as by environmental policies. Nature conservation organisations are often unpopular, as farmers feel restricted by how they, together with the national government, limit their agrarian productivity through requirements regarding manure, pesticides, groundwater levels, etc.

In this language of valuation, shale gas extraction would be another way to restrict farmers' productivity. However, not only farmers, also people involved in related agri-businesses voice this worry. For them, to oppose shale gas is a rational choice based on a cost-benefit analysis, 
rooted in this idea of being productive. This is in line with what McGuire et al. (2013) call 'productivist identity', which often dominates in farming decisions. Annette for example, businesswoman by heart, considers shale gas extraction a 'short time profit with low returns, it destroys the land, perhaps forever [...] purely based on a cost benefit analysis nobody will start fracking here'. ${ }^{13}$ André, an organic farmer, believes that eventually the national government will make this cost-benefit analysis as well and come to the right conclusion: 'in the end they will not pursue this shale gas story, we are an agricultural area par excellence'.$^{14}$

'The Noordoostpolder as productive land' is a language of valuation that is used in anti-shale gas resistance. Because it can be made visible and tangible in calculations and models, it provides opponents of shale gas with powerful arguments in the political discussion. Several opponents to shale gas have, for example, warned that shale gas exploration could induce a decline in real estate value across the Noordoostpolder by $10 \%{ }^{15}$ Also, a study conducted by CE Delft concluded that commercial exploitation of shale gas in the Noordoostpolder would lead to a local economic damage between 120 and 1400 million Euro, taking into account real estate value, and the agrarian and recreational economic sectors (CE-Delft 2016).

In contrast to 'the Noordoostpolder as the land-of-the-pioneers', productivity is viewed as an argument that does count in political discussions and is therefore developed into a politics of belonging as argument to claim rights in the debate on shale gas developments. Belonging through economic activity can be translated into what our research participants consider neutral and objective arguments because it is based on calculations and models and not on sentiments and emotions. In line with this, resisting shale gas is at times approached as a business. As Bram explains: 'we aren't activists, we will rather work in a business-like way. We approach this as a project to be managed, a project to simply stop it'. And he adds: 'protests from the business 
community will weigh more in political decision-making than mere citizens protest ... also because the business community is the primary constituency of Kamp'. ${ }^{16}$ The economic argument can easily be conveyed in technical, scientific language. Such representations are believed to be politically strong because they fit with local (and national) authorities' sentiment that policy should be based on 'firm evidence and fact' (Woods 2003).

The polder as a source for economic development 'We need some economic activities to generate money'. ${ }^{17}$

'It's there, if we can find a way to get it out in a clean way, then there is no reason why we should not do so, to make a profit, as a way forward' 'It will just bring some activity, ... and that is something that just needs to be well organised. ${ }^{18}$

The language of valuation that emphasises the polder as a source for economic development is closely related to the language of productivity, expressing the value of entrepreneurialism as something that people feel at home with. However, its outcome for shale gas extraction is opposite as arguments are differently weighed. In the above quotes Gerard and René voice the local arguments that are used in favour of possible shale gas extraction in the Noordoostpolder, resonating the neoliberal framework that is used to justify hydraulic fracturing (Willow 2016). The potential monetary value of the Noordoostpolder is central in this language of valuation. In addition, the quotes echo the 'business as usual argument' (Metze 2016): no harm will be done if the extraction process is managed well.

The belief that shale gas extraction can happen in a clean way and be managed well, makes it possible to see shale gas extraction as compatible with the language of valuation that underlines the agricultural meaning of the Noordoostpolder as productive land. Gerard for example is quick 
to acknowledge the Noordoostpolder as prime farmland, but does not see this as contradictory to hydraulic fracturing: 'we produce the cleanest and the best food of the world, but that is still possible with drilling rigs on the land'. How shale gas can be a source of economic development for the polder in this language of valuation is not very specific yet, but refers to things like compensation payments for the use of land or opportunities for local companies to provide services to the drilling company. One of the farmers on whose land the exploration drillings are planned, puts it like this: 'If they're coming anyway, I'd better make use of it'. But he also thinks that there should be some financial benefits for the larger community: 'The government should make sure that the permit includes some benefits for the community, like new bicycle roads or something'.

In this monetary language of valuation, neutrality and objectivity are considered important arguments in the political debate. Gerard for example rejects the irrational, emotional tone that is, according to him, dictating the debate: 'fear stops the debate [...] decisions are based on emotions rather than on information'. A decision on shale gas should thus be a business-like decision that is not guided by emotions. As René put it: 'I'm not too democratic. If Kamp (the responsible minister) comes with a thorough study, he should push his plan through [...] otherwise we would still live in the Stone Age'. Members of the local branch of the liberal party have already mobilised this language of valuation as political argument, developing it into a politics of belonging when the discussions about shale gas in the polder had just begun. By arguing that shale gas would provide the polder with economic activity and jobs that would be badly needed in the future, they express their belonging to the polder as shaped by entrepreneurialism emphasising a monetary meaning. However, after the municipality declared itself shale gas free in 2013, this point of view has not been articulated a lot. People in favour of 
shale gas have, for example, not organised socially. This does not mean, however, that everybody is against shale gas exploration. Many people utter a need for more research so they can base their position on facts and scientific knowledge.

The Noordoostpolder as a landscape of regularity and tranquillity

'First, I had drawn a circle with a pair of compasses around Amsterdam, where I worked. The Noordoostpolder was within the scope of the amount of kilometres I had set - I didn't want to travel more than one hour to my work. On arrival in the Noordoostpolder I stepped out of my car and I heard ... nothing. And I knew: this is where I want to live' ${ }^{19}$

Marcel is one of many research participants who expressed how the tranquillity and spaciousness of the rural landscape is key to his feeling at home in the polder. Polder residents appreciate the steady rhythm of small villages, rural roads, fields of pre-defined sizes and standardised farmhouses, barns and workers' houses pitched on equal distances from each other. Place-belongingness in this language of valuation is shaped in interaction with the physical environment (Poe et al., 2014) of which regularity and tranquillity are important elements. The possible visibility of shale gas extraction in terms of rigs, increased infrastructure and transport, are considered as completely contrary to these Noordoostpolder landscape values.

Residents and local politicians celebrate the uniqueness of the Noordoostpolder landscape, which finds it origins in its initial design. People were to live on an acceptable distance from shops and other facilities. Therefore, distances between villages are never more than 8 kilometres in order to secure access to shops and facilities (Feddes/Olthof 2012). A fixed lot size of $300 \times 800$ meters and a fixed pattern of farm courtyards clustering was applied throughout 
the whole polder, adding to the experience of regularity and providing 'unity and coherence' (Feddes/Olthof, 2012). The municipality emphasises the importance of maintaining the unique elements of 'regularity, peacefulness and quietness' (Municipality Noordoostpolder 2013). Possible landscape pollution is, consequently, one of the reasons for the municipality to withstand shale gas extraction. Also individuals emphasise how they are afraid that the place they call their home will change through shale gas developments. Marcel for example says: 'this is one of the cleanest places in the Netherlands ... now we might run into round-the-clock noise'. Other interviewees mention the horizon pollution because of the many rigs, as well as the increase in transportation and its implications for road safety as arguments against shale gas.

Although the Noordoostpolder was designed to produce food, some parts of the land were not suitable for agriculture and were turned into forests earmarked as nature. Nonetheless, the municipal council resisted the designation of two Natura $2000^{20}$ areas on the adjacent old land in $2013,{ }^{21}$ because this could restrict the room of manoeuvre of its farmers and recreational entrepreneurs. ${ }^{22}$ However, in the case of possible hydraulic fracturing, nature conservation organisations are seen as possible allies. Conservation of the Natura 2000 area could make for a good argument against fracking. However, research participants do not display an interest in keeping nature untouched, it is rather the Noordoostpolder landscape of agricultural development that has become people's homes that constitutes belonging.

Landscape is valued as important; its core characteristics of regularity and tranquillity make people feel at home. How this is uses in arguments to claim rights and thus becomes part of the politics of belonging differs per actor. For the two citizens groups active in the polder it is at the top of their lists of arguments against shale gas, emphasising the amount, size and looks of the exploration sites and the height of drilling rigs. ${ }^{23}$ 'Tegengas' only mentions landscape pollution 
in its relation to possible economic damage, linking it up to the productivity language of valuation. Two national environmental organisations, Natuurmonumenten ${ }^{24}$ and the Dutch Friends of the Earth, have used the landscape argument, calling on the government to take her legal responsibility seriously and give due consideration to how shale gas extraction may affect these landscape characteristics like silence, broad views and darkness. ${ }^{25}$

The polder as a place to produce renewable energy Mirjam and Henk proudly show us the neat five by five meters patch of grass with a small tree in the middle that marks the drilling location of their heat pump. The roof of the barn at the back of the garden is partly covered with solar panels and inside the barn there is an installation that converts the solar energy to household voltage. There is also a large amount of firewood, imported from the Baltics, to feed the heat-accumulating fire stove. Together these systems provide the energy for their home, which used to be a bottomless pit in terms of energy bills, but after years of putting up extra isolation and installing new technologies, hasn't used any nonrenewable energy sources since $2013 .^{26}$

Mirjam and Henk invest in renewable energy solutions like solar panels and heat pumps, and they are not the only ones. In the Noordoostpolder renewable energy is produced in many different ways by a variety of actors that see the Noordoostpolder as a sustainable place. Shale gas opponents link the production of renewable energy discursively to being against fracking. In this language of valuation place-belongingness is constructed through sharing the same values (Mulgan 2016): sustainability and entrepreneurship.

The Noordoostpolder is a proud renewable energy 'frontrunner' of Dutch municipalities, planning to become energy neutral in 2030. It is investing in solar panels on municipal buildings 
and subsidising renewable energy in private houses. Moreover, 'Windpark Noordoostpolder' finished in 2016, produces 1,4 billion Kwh per year, putting this municipality first in the Netherlands in terms of wind energy while also boasting the largest amount of solar panels per inhabitant. ${ }^{27}$ Whereas the municipality prides itself for its renewable energy, it owes part of its achievements to farmers' entrepreneurship: 74 out of 86 windmills are owned by farmers' cooperatives. ${ }^{28}$ Apart from the windmill park - solitary windmills are not allowed anymore because of landscape considerations - there are several farmers that have the roofs of their barns filled up with up to 2000 solar panels as a business investment. Although not all people who invest in renewable energy do so from an idealistic perspective, they do contribute to the promoted image of a sustainable municipality.

Besides big business renewable energy projects, there are also quite some individuals who engage in renewable energy initiatives. Some based on the value of sustainability, others just like to see the technological challenge of becoming energy neutral. Often it is a combination of both. In the case of Mirjam and Henk for example, Henk says that he considers it a challenge to be autonomous, 'off the grid'. Mirjam reflects on it differently; being part of the anti-shale gas mobilisation made her reflect on her own life style, and as such investing in an energy-neutral home became more important for her. ${ }^{29}$ Also Pieter relates being against shale gas directly to a sustainable life style: 'I have chosen to put children in this world, so you have to take your responsibility. (...) This means that I produce my food in my own kitchen garden and try to stay away from fossil fuels as much as possible, so of course I am not in favour of shale gas'.

'The polder as a place to produce renewable energy' as a language of valuation expresses how people belong to the Noordoostpolder through the ideas of sustainability in relation to entrepreneurial engagement. This facet of belonging has now also turned into an important 
(discursive) resource. Arguments about how the Noordoostpolder is a place to produce renewable energy are used in a politics of belonging where residents claim rights to be part of the community that decides upon energy production. 'Tegengas' promotes renewable energy both as argument and practice. As an argument, renewable energy production is put forward as alternative to shale gas as it is cleaner and less risky, but also because the production of shale gas will delay investments in renewable energies. Some 'Tegengas' members engage in the production of renewable energy for this reason. They install solar panels and heat pumps in their houses, promote such investments through citizen initiatives and in the municipal board, or participate in wind parks. Renewable energy is considered the Noordoostpolder answer to shale gas: 'Let's show minister Kamp that we, the inhabitants of the Noordoostpolder, can produce energy from renewable sources at a lower cost than Cuadrilla through fracking'.

\section{Discussion and conclusion}

The central aim of this article was to analyse belonging in relation so shale gas developments. This analyses comprises of three elements: first, which elements of belonging become articulated; second, how do these elements, as they are reflected in languages of valuation, shape the ways people position themselves and develop political voice towards possible shale gas extraction; and third, which of these elements are translated into political claims in the course of social mobilisation. To do so, we unpacked the construction of place-belongingness in the Noordoostpolder, disclosing that the values that guided the making of the polder in the late 1930s and early 1940s not just constitute important elements of place-belonging today, but are also important for understanding how place-belongingness is used politically in the course of social mobilisation against shale gas. 
So, the first first level of analysis examines which elements of belonging are articulated in relation to shale gas and hydraulic fracturing and how these elements are constructed in time and space. Our ethnographic unravelling of languages of valuation shows that different facets of place-belongingness in the Noordoostpolder are rooted in its specific history of being a 'human-made' agricultural society. The shared memory of the pioneer past is an important autobiographical facet of place-belongingness (Antonsich 2010). Other facets of placebelongingness that shape how people relate to shale gas are rooted in the societal and economic ideas that informed the creation of the Noordoostpolder. The strict selection of excellent famers gave way for the development of the economic facet of place-belongingness: the polder as a new agricultural society. The regular and tranquil landscape is another important element of place-belongingness; it makes people feel at home and structures their interaction with the landscape. More recently, partly as a reaction to proposed shale gas extraction, sustainability as a shared value has come to the fore as an element of place-belongingness.

Our second level of analysis examines the ways these elements of belonging relate to and shape the process of taking position towards shale gas developments. We have shown that how people experience and position themselves regarding proposed extractive projects is shaped by their engagement with the polderland, memories of pioneering, and shared values of sustainability and economic security. The characteristics of shale gas extraction - rigs in the landscape, drilling in human-made land, endangering agricultural production and export by use of chemicals, impeding the transition towards renewable energy - are considered incompatible with these meanings. Only the language of valuation that describes the polder as a source for economic development celebrates shale gas exploration as compatible with agriculture. This resonates with other studies that have showed that land and landscapes are important in mobilising 
belonging as a way of resisting fracking (Willow et al., 2014) and that citizens focus on community continuity, political empowerment, and environmental sustainability (Willow, 2016; Vesalon \& Creţan, 2015) rather than on the monetary value of resources.

All languages of valuation related to shale gas developments contain an element of voice and political agency at the level of 'feeling at home'. The farmer who gets the last say in how to make his land productive, the entrepreneur who makes decisive cost-benefit analyses, the descendant of pioneers with a substantial role in community organising: they come from different but overlapping social places and all claim a voice in land and resource use. Their positionining against shale gas exploration and exploitation is thus not only about shale gas and its consequences, but also about the political process, about finding a way to express political agency and voice, in the process surrounding its regulation and development (Bomberg 2015, Vesalon \& Creţan 2015).

Finally, moving on to the third level of analysis, we analysed why some aspects of belonging are used in anti-shale gas mobilisations, while others are not. We demonstrated that although all languages of valuation contain an element of voice and an idea of who has the authority to decide on land use, not all languages of valuation become translated into political claims in a politics of belonging. These are only the valuations that are considered the most 'factual' and 'objective', or useful as policy solution, and therefore expected to be most valid in competition with the more monetary language of valuation. Opponents of shale gas hope to strengthen their political position by referring to those meanings of the Noordoostpolder that, according to them, translate well into political arguments because these are based on facts (Woods, 2003; Chilvers \& Kearnes, 2015). Based on this logic, the languages of productivity, renewable energy, and to a far lesser extent, of landscape, are used as political arguments because they encompass 
numbers and facts that are perceived as objective, or, in the case of renewable energy, because it is considered as the only practical answer and policy solution to fossil fuels. Important affective elements of place-belongingness, such as the pioneer past, are not brought forward in the course of social organizing. Translating personal concern about shale gas extraction thus involves transforming emotional attachments into politically useful 'facts' and 'figures'.

\section{Endnotes}

1 See for example two recent special issues: Environmental Communication (2016) Vol.10 (3), Communicating Hydrofracking and Journal of Environmental Policy and Planning (2017) Vol. 19 (1).

2 Most social science research has been devoted to this area. Examples are: Brasier, K. J., Filteau, M. R., McLaughlin, D. K., Jacquet, J., Stedman, R. C., Kelsey, T. W., \& Goetz, S. J. (2011). Residents' perceptions of community and environmental impacts from development of natural gas in the Marcellus Shale: a comparison of Pennsylvania and New York cases. Journal of Rural Social Sciences, 26(1), 32-61; Hudgins, A., \& Poole, A. (2014). Framing fracking: private property, common resources, and regimes of governance. Ecology, 21, 222-348; Matz, J., \& Renfrew, D. (2015). Selling "fracking": Energy in depth and the Marcellus Shale. Environmental Communication, 9(3), 288-306; Perry, S. L. (2012). Development, land use, and collective trauma: the Marcellus Shale gas boom in rural Pennsylvania. Culture, Agriculture, Food and Environment, 34(1), 81-92; Plantan, E. (2014). Framing Effects and Mobilization along the Marcellus Shale. Paper presented at the APSA 2014 Annual Meeting Paper. 
explained/index.php/Energy from renewable sources (accessed October 13, 2016)

4

http://aardgas-in-nederland.nl/nederland-aardgasland/aardgas-in-de-nederlandseenergievoorziening/\#1 (accessed October 13, 2016)

5

http://www.eenvandaag.nl/binnenland/45003/brits bedrijf wil ook schaliegas uit flevopold er (accessed December 20, 2015)

6 Tegengas in Dutch means 'against gas', but also 'countermovement'.

7 See also www.tegengasnop.nl

8 Fieldnotes, September 2014.

9 http://www.canonnoordoostpolder.nl/ accessed on 6 October 2016. Other examples are: a statue of a pioneer a vacation home, a school and a yearly price all named after the pioneers. http://www.rt49.nl/polderpionier/, http://www.denoordoostpolder.nl/nieuws/52054/reuniebij-65-jarige-obs-de-pionier-uit-kraggenburg/, http://gastvrijschokland.nl/de-pionier 10 http://www.pioniersvandetoekomst.nl/ accessed on 6 October 2016

11 LTO is the Dutch entrepreneurial and employers' organisation for agriculture and horticulture. The meeting was at the Noordoostpolder branch of the LTO.

12 Fieldnotes LTO meeting, March 31, 2015.

13 Interview Annette 2015.

14 Interview André 2014.

15 In discussions in the Noordoostpolder this number is often attributed to Rabobank calculations and therefor seen as valid. The number is based on a Greenpeace UK commissioned research conducted by marketing research agency Redshift 
http://www.greenpeace.org.uk/media/press-releases/estate-agents-warn-fracking-will-hit-

house-values-20150501, accessed on October 11, 2016.

16 Interview Bram (Kamp is the present minister responsible for the shale gas policies)

17 Gerard, interview 2014.

18 René, interview 2014.

19 Marcel, interview 2014.

20 Natura 2000 is a EU nature conservation policy.

21 http://www.rtvoost.nl/nieuws/default.aspx?cat=1\&nid=209491, accessed 12 October 2016.

22 http://www.rtvoost.nl/nieuws/default.aspx?cat=1\&nid=209491, accessed 12 October 2016.

23

http://schaliegasvrijnoordoostpolder.nl/onze-argumenten/,

http://www.werkgroepschaliegasneenoordoostpolder.nl/ both accessed on 7 October 2016.

24 Natuurmonumenten means 'Nature monuments'.

25 Milieudefensie in their so called 'Zienswijze' a formal letter dated 4 July 2014 to Minister Kamp as part of an Environmental Impact Assessment.

26 Fieldnotes, December 2015.

27

http://www.windstats.nl/statistiek.php,

http://www.denoordoostpolder.nl/nieuws/71810/nop-gemeente-met-meeste-zonnepanelen/ both accessed on 7 October 2016.

28

http://www.westermeerwind.nl/project/feiten-cijfers-en-planning/,

http://www.windparknoordoostpolder.nl/windpark/ and http://www.nopagrowind.nl/ all accessed on 7 October 2016.

29 Interview Mirjam and Henk 2015. 


\section{Bibliography}

Antonsich, M. (2010) Searching for belonging-an analytical framework. Geography compass. 4(6) pp. 644-659

Barth, J. M. (2013) The economic impact of shale gas development on state and local economies: Benefits, costs, and uncertainties. New solutions: $A$ journal of environmental and occupational health policy. 23(1) pp. 85-101

Bomberg, E. (2015) Shale we drill? Discourse dynamics in UK fracking debates. Journal of Environmental Policy \& Planning, pp.1-17

Boudet, H., Clarke, C., Bugden, D., Maibach, E., Roser-Renouf, C., \& Leiserowitz, A. (2014) "Fracking" controversy and communication: Using national survey data to understand public perceptions of hydraulic fracturing. Energy policy. 65 pp. 57-67.

Brasier, K. J., Filteau, M. R., McLaughlin, D. K., Jacquet, J., Stedman, R. C., Kelsey, T. W., \& Goetz, S. J. (2011) Residents' perceptions of community and environmental impacts from development of natural gas in the Marcellus shale: a comparison of Pennsylvania and New York cases. Journal of Rural Social Sciences. 26(1) pp. 32-61

Buonfino , A., \& L. Thomson (2007) Belonging in contemporary Britain (West Yorkshire: Communities and Local Government Publications)

Burton, R. J. (2004) Seeing through the 'good farmer's' eyes: towards developing an understanding of the social symbolic value of 'productivist' behaviour. Sociologia ruralis. 44(2) pp. $195-215$ 
CE-Delft (2016) Economische effecten schaliegaswinning in de Noordoostpolder (Delft: CE Delft)

Chilvers, J. and Kearnes, M. (eds.). 2015. Remaking participation: Science, environment and emergent publics (London: Routledge)

Colborn, T., Kwiatkowski, C., Schultz, K., \& Bachran, M. (2011) Natural gas operations from a public health perspective. Human and ecological risk assessment: An International Journal. 17(5) pp. 1039-1056.

Constandse, A. K. (1958) Acquaintanceships of farmers in a newly colonized area. Social compass. 6(2) pp. 69-74

Correljé, A., Cuppen, E., Dignum, M., Pesch, U., Taebi, (2015). Responsible innovation in energy projects: Values in the design of technologies, institutions and stakeholder interactions. Pp. 183-200 in B.-J.Koops, Oosterlaken, I., Romijn, H., Swierstra, T., van den Hoven, J. (Eds.) Responsible Innovation 2, Springer International Publishing.

Cotton, M., Rattle, I., \& Van Alstine, J. (2014). Shale gas policy in the United Kingdom: An argumentative discourse analysis. Energy policy, 73, 427-438.

Cuppen, E., Pesch, U., Remmerswaal, S., Taanman, M., 2016. Normative diversity, conflict and transition: Shale gas in the Netherlands. Technological forecasting and social change, in press: http://dx.doi.org/10.1016/i.techfore.2016.11.004.

Davis, C., \& Fisk, J. M. (2014) Energy abundance or environmental worries? Analyzing public support for fracking in the United States. Review of Policy Research. 31(1) pp. 1-16. 
De Rijke, K. (2013a) Hydraulically fractured: Unconventional gas and anthropology.

Anthropology today. 29(2) pp. 13-17

De Rijke, K. (2013b) The agri-gas fields of Australia: Black soil, food, and unconventional gas.

Culture, agriculture, food and environment. 35(1) pp. 41-53.

Duyvendak, J. W. (2011). The politics of home: belonging and nostalgia in Europe and the United States. (Hampshire: Palgrave Macmillan)

Eaton, E., \& Kinchy, A. (2016) Quiet voices in the fracking debate: Ambivalence, nonmobilization, and individual action in two extractive communities (Saskatchewan and Pennsylvania). Energy research \& social science. (20) pp. 22-30.

Entrekin, S., Evans-White, M., Johnson, B., \& Hagenbuch, E. (2011) Rapid expansion of natural gas development poses a threat to surface waters. Frontiers in ecology and the environment. 9(9) pp. 503-511

Feddes/Olthof landschapsarchitecten ( 2012) Landschapsvisie Noordoostpolder; landschap van rust en regelmaat (Utrecht: FeddesOlthof)

Finewood, M. H., \& Stroup, L. J. (2012) Fracking and the Neoliberalization of the Hydro-Social Cycle in Pennsylvania's Marcellus Shale. Journal of Contemporary water research \& education. 147(1) pp. 72-79

Flokstra, TJ (2000) Samenleven in het nieuwe land. Een schets van de sociale, culture en geestelijke ontwikkelingen in de Noordoostpolder 1942-1970 (Kampen: Stichting IJsselacademie) 
Gerharz, E. (2014). Indigenous activism in Bangladesh: translocal spaces and shifting constellations of belonging. Asian ethnicity, 15(4), 552-570.

Groenman, S., Bazlen, K. A and Sieben, W.H. 1952. Land in wording - Het nieuwe hart van Nederland - De Zuiderzee bedwongen, (Meppel: Roelofs van Goor).

Groenman, S. (1952) Physical planning in reclaimed and newly colonized areas. Soil science. 74(1) pp. 97-101

hooks, B. (2009) Belonging: A culture of place (New York: Routledge)

Howarth, R. W., Santoro, R., \& Ingraffea, A. (2011) Methane and the greenhouse-gas footprint of natural gas from shale formations. Climatic change. 106(4) pp. 679-690.

Hudgins, A. (2013) Fracking's future in a coal mining past: Subjectivity undermined. Culture, agriculture, food and environment. 35(1) pp. 54-59

Hulten, M. V. (1969) Plan and reality in the ljsselmeerpolders. Tijdschrift voor economische en sociale geografie. 60(2) pp. 67-76

Jacquet, J. B. (2012) Landowner attitudes toward natural gas and wind farm development in northern Pennsylvania. Energy Policy. 50 pp. 677-688.

Lähdesmäki, T., Saresma, T., Hiltunen, K., Jäntti, S., Sääskilahti, N., Vallius, A., \& Ahvenjärvi, K. (2016) Fluidity and flexibility of "belonging" Uses of the concept in contemporary research. Acta sociologica. 59 (3) pp. 233-247

Lewicki, R. J., Gray, B., \& Elliott, M. (2003). Making sense of intractable environmental conflicts: Concepts and cases. (Washington, DC: Island Press). 
Martinez-Alier, J. (2001). Mining conflicts, environmental justice, and valuation. Journal of hazardous materials. 86(1) pp. 153-170

Martinez-Alier, J. (2014) The environmentalism of the poor. Geoforum. 54 pp. 239-241

Martinez-Alier, J., L. Temper, D. Del Bene and A. Scheidel (2016) Is there a global environmental justice movement? The journal of peasant studies. 43(3) pp. 731-755

McGuire, J., Morton, L. W., \& Cast, A. D. (2013). Reconstructing the good farmer identity: Shifts in farmer identities and farm management practices to improve water quality. Agriculture and human values, 30(1), 57-69.

Mercer, A., de Rijke, K., \& Dressler, W. (2014) Silences in the midst of the boom: Coal seam gas, neoliberalizing discourse, and the future of regional Australia. Journal of Political Ecology. 21 pp. 279-302.

Metze, T. (2014). Fracking the debate: Frame shifts and boundary work in Dutch decision making on shale gas. Journal of environmental policy \& planning, http://dx.doi.org.ezproxy.library.wur.nl/10.1080/1523908X.2014.941462 Mulgan, G. (2009) Feedback and belonging: Explaining the dynamics of diversity. Migration Policy Institute: http://www.migrationpolicy.org/article/feedback-and-belonging-explainingdynamics-diversity/, Accessed on October 12, 2016.

Niska, M., Vesala, H. T., \& Vesala, K. M. (2012) Peasantry and entrepreneurship as frames for farming: reflections on farmers' values and agricultural policy discourses. Sociologia ruralis. 52(4) pp. 453-469 
Perry, S. L. (2011). Energy consequences and conflicts across the global countryside: North American agricultural perspectives. Forum on public policy. 2 pp. 1-23.

Perry, S.L. (2012) Environmental reviews and case studies: Addressing the societal costs of unconventional oil and gas exploration and production: A framework for evaluating shortterm, future, and cumulative risks and uncertainties of hydrofracking. Environmental practice. 14(4) pp. 352-365

Ploeg, J. D. Van der (2009) The new peasantries: struggles for autonomy and sustainability in an era of empire and globalization (London: Routledge)

Poe, M., LeCompte, J., McLain, R., \& Hurley, P. (2014) Urban foraging and the relational ecologies of belonging. Social \& cultural geography. 15(8) pp. 901-919

Poole, A., \& Hudgins, A. (2014) "I care more about this place, because I fought for it": Exploring the political ecology of fracking in an ethnographic field school. Journal of environmental studies and sciences. 4(1) pp. 37-46

Probyn, E. (1996) Outside belongings (London: Routledge)

Simonelli, J. (2014) Home rule and natural gas development in New York: Civil fracking rights. Journal of political ecology. (14) pp. 258-278

Vandergeest, P., \& Peluso, N. L. (1995) Territorialization and state power in Thailand. Theory and society. 24(3) pp. 385-426.

Vesalon, L., \& Creţan, R. (2015) 'We are not the Wild West': anti-fracking protests in Romania. Environmental Politics. 24(2) pp. 288-307. 
Willow, A. (2014) The new politics of environmental degradation: Un/expected landscapes of disempowerment and vulnerability. Journal of political ecology. (21) pp. 237-257

Willow, A. J. (2016) Wells and well-being: neoliberalism and holistic sustainability in the shale energy debate. Local environment. 21(6) pp. 768-788.

Willow, A.J., R. Zak, D. Vilaplana and D. Sheeley (2014) The contested landscape of unconventional energy development: A report from Ohio's shale gas country. Journal of environmental studies and sciences. 4(1) pp. 56-64

Woods, M. (2003) Conflicting environmental visions of the rural: Windfarm development in Mid Wales. Sociologia ruralis. 43 (3) pp. 271-288

Yuval-Davis, N. (2006) Belonging and the politics of belonging. Patterns of prejudice. 40 (3) pp. $197-214$

Yuval-Davis, N. (2007) Intersectionality, citizenship and contemporary politics of belonging. Critical review of international social and political philosophy. 10(4) pp. 561-574. Yuval-Davis, N. (2011). The politics of belonging: Intersectional contestations (London: Sage) 